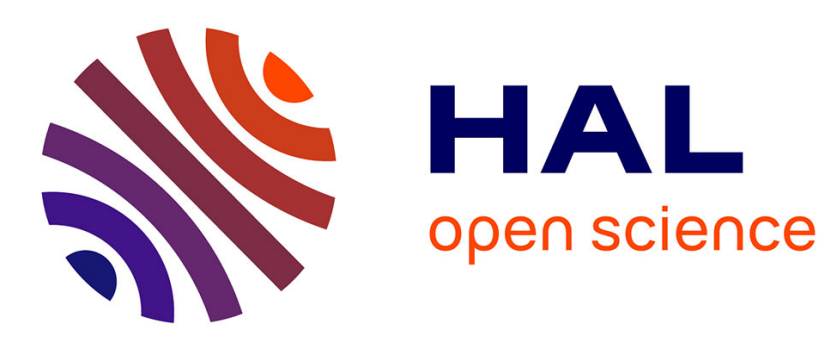

\title{
The reactive element effect (REE) in oxidation of alloys
}

\author{
Yasutoshi Saito, Bülent Önay, Toshio Maruyama
}

\section{To cite this version:}

Yasutoshi Saito, Bülent Önay, Toshio Maruyama. The reactive element effect (REE) in oxidation of alloys. Journal de Physique IV Proceedings, 1993, 03 (C9), pp.C9-217-C9-230. 10.1051/jp4:1993920 . jpa-00252357

\section{HAL Id: jpa-00252357 https://hal.science/jpa-00252357}

Submitted on 1 Jan 1993

HAL is a multi-disciplinary open access archive for the deposit and dissemination of scientific research documents, whether they are published or not. The documents may come from teaching and research institutions in France or abroad, or from public or private research centers.
L'archive ouverte pluridisciplinaire HAL, est destinée au dépôt et à la diffusion de documents scientifiques de niveau recherche, publiés ou non, émanant des établissements d'enseignement et de recherche français ou étrangers, des laboratoires publics ou privés. 


\title{
The reactive element effect (REE) in oxidation of alloys (*)
}

Yasutoshi Saito $\left({ }^{1, * *}\right)$, Bülent Önay $\left({ }^{2, * *}\right)$ and Toshio Maruyama $\left({ }^{3}\right)$

( $\left.{ }^{1}\right)$ National Institution for Academic Degrees, 4259 Nagatsuta-cho, Midori-ku, Yokohama 227, Japan

(2) High Temperature Materials Section, 2nd Materials Department, Hitachi Research Laboratory, Hitachi Ltd., 3-1-1 Saiwai-cho, Hitachi-shi, Ibaraki-ken 317, Japan

$\left({ }^{3}\right)$ Department of Metallurgical Engineering, Tokyo Institute of Technology, 2-12-1, Ookayama, Meguro-ku, Tokyo 152, Japan

\begin{abstract}
The reactive element effect (REE) in high temperature oxidation is discussed, for chromia-forming alloys, in terms of a mechanistic model based on postulations that (a) reactive element/oxide additions promote nucleation of $\mathrm{Cr}_{2} \mathrm{O}_{3}$ and (b) reactive element-oxides react with $\mathrm{Cr}_{2} \mathrm{O}_{3}$ to form perovskite-type compounds, such as $\mathrm{YCrO}_{3}$, along scale boundaries which promote inward oxygen diffusion. The standard Gibbs energy of formation and concentrations of ionic defects for $\mathrm{YCrO}_{3}$ are calculated. For silicon-containing chromia-forming alloys, the degradation of the scale adherence is shown to be the result of the $\alpha-\beta$ phase transformation in cristobalite. Morphologies of alumina scales formed over yttrium-containing $\mathrm{Fe}-20 \mathrm{Cr}-4 \mathrm{Al}$ alloys indicated that yttrium increased the stability of metastable alumina phases at $1173 \mathrm{~K}$ and decreased the amount of wrinkling in the $\alpha$-alumina scale at $1273 \mathrm{~K}$.
\end{abstract}

\section{Introduction.}

The beneficial effects of oxygen-active elements such as yttrium and cerium on the oxidation behavior of high temperature alloys are known for more than 50 years. The current understanding of this, so called, "reactive element effect" (REE) has been discussed, most recently, by Saito and Önay [1] and by Stringer [2]. Specifically, for chromia-forming alloys, the additions of reactive elements/oxides promote the formation of the chromia scale, decrease its growth rate and improve its adherence to the alloy substrate. For alumina-forming alloys the REE is, most importantly, observed on the improvement of the adherence of the scale. The vast experimental data reported in the literature indicate that the REE is realized regardless of the mode of addition of the reactive element to the alloy. These include alloying additions of the reactive element or its oxide, ion implantation of the element and superficial application of the reactive element oxide as a thin coating over the alloy.

Although several different theories have been proposed for the REE in oxidation of high temperature alloys, currently no single theory can explain all of the experimental findings. In this paper, one of these models, as proposed earlier by Saito and Maruyama [3], is discussed in terms of the thermodynamic and defect properties of the oxide phases involved in the

(*) Keynote lecture.

$\left({ }^{* *}\right)$ Former address: Research Laboratory for Nuclear Reactors, Tokyo Institute of Technology, 2-19-1, Ookayama, Meguro-ku, Tokyo 152, Japan. 
oxidation of simple chromia-forming alloys. Some recent observations of the REE on the morphology of the alumina scales formed on Fe-base alloys are also discussed.

\section{The REE in chromia-forming alloys.}

The reactive element/oxide additions to chromia-forming alloys have been observed to:

a) decrease the amount of chromium required for the formation of the protective chromia scale;

b) decrease the growth rate of the scale and modify its growth mechanism;

c) improve the scale adherence upon thermal cycling of the substrate.

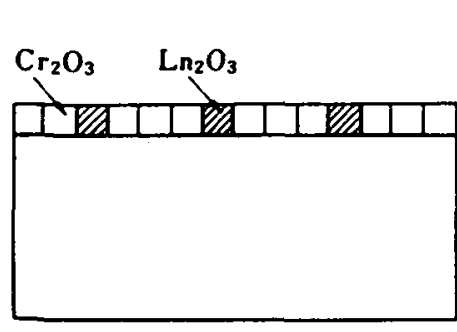

(a)

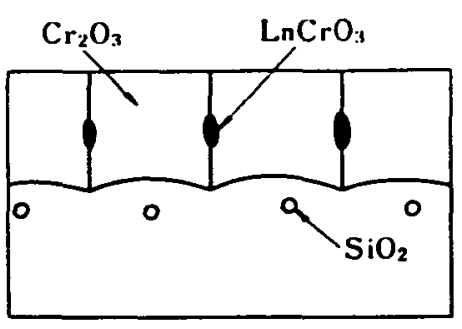

(b)

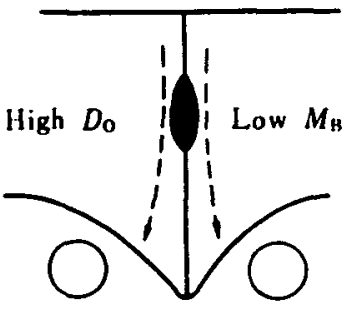

(c)

Fig. 1. - Schematic illustration of the mechanistic model proposed to explain the REE on the growth mechanism of chromia scale.

Figure 1 is the schematic illustration of the mechanistic model proposed by two of the present authors to explain these observations in chromia-forming alloys. According to this model, the chromia scale formation over the alloy is enhanced by its preferential nucleation at the reactive element oxide particles either applied superficially over the alloy surface or formed upon oxidation of the element in the alloy (Fig. 1a). During growth of the scale, the reactive element oxide particles react with $\mathrm{Cr}_{2} \mathrm{O}_{3}$ to form perovskite-type compounds such as $\mathrm{YCrO}_{3}$ or $\mathrm{CeCrO}_{3}$ depending on the reactive element/oxide present in the alloy (Fig. $1 \mathrm{~b}$ ). These compounds act as short-circuit diffusion paths for oxygen in the scale while blocking cation diffusion. This enhancement in oxygen diffusion through the scale (indicated as $D_{\mathrm{O}}$ in Fig. 1c) promotes the formation of the keying-on structure at the alloy-scale interface through oxidation of less noble alloy components, such as $\mathrm{Si}$, close to that interface. Such an irregular interface and the absence of voids are thought to be reasons for the improved chromia scale adherence. Furthermore, the perovskite-type compounds present at the scale grain boundaries prevent boundary migration (indicated as "low $M_{\mathbf{B}}$ " in Fig. Ic), thus causing the development of a fine-grained scale with improved mechanical properties. In the following sections, experimental data related to the thermodynamic and defect properties of such perovskite-type compounds are presented to provide support for this mechanistic model for the REE in chromia-forming alloys.

2.1 THERMODYNAMIC PROPERTIES OF $\mathrm{YCrO}_{3}$. - The standard Gibbs energy of formation of $\mathrm{YCrO}_{3}$ was determined by an electrochemical technique using a solid electrolyte. For this purpose, yttrium chromite powder was prepared by the drop pyrolysis method by which 
the nitrate solution containing yttrium and chromium ions was injected drop by drop into a container placed in a furnace preheated to $1073 \mathrm{~K}$. The $\mathrm{YCrO}_{3}$ powder in the container was pressed into pellets and sintered at $1673 \mathrm{~K}$ for $14.4 \mathrm{ks}$.

The electromotive force (EMF) measurements were performed in air at temperatures between 1202 and $1414 \mathrm{~K}$ using the following cell arrangement with yttrium phosphate, $\mathrm{YPO}_{4}$, which behaves as a yttrium-ion conductor.

$$
\mathrm{Pt}, \mathrm{O}_{2}, \mathrm{Y}_{2} \mathrm{O}_{3}\left|\mathrm{YPO}_{4}\right| \mathrm{YCrO}_{3}, \mathrm{Cr}_{2} \mathrm{O}_{3}, \mathrm{O}_{2}, \mathrm{Pt}
$$

the anode reaction in the cell is expressed as

$$
\mathrm{Y}_{2} \mathrm{O}_{3} \rightarrow 2 \mathrm{Y}^{3+}+(3 / 2) \mathrm{O}_{2}+6 \mathrm{e}^{-}
$$

and the cathode reaction as

$$
\mathrm{Cr}_{2} \mathrm{O}_{3}+2 \mathrm{Y}^{3+}+(3 / 2) \mathrm{O}_{2}+6 \mathrm{e}^{-} \rightarrow 2 \mathrm{YCrO}_{3}
$$

Thus, the overall cell reaction can be written as

$$
\mathrm{Y}_{2} \mathrm{O}_{3}+\mathrm{Cr}_{2} \mathrm{O}_{3} \rightarrow 2 \mathrm{YCrO}_{3}
$$

The EMF of this cell is given by the following equation

$$
E=-\left(\Delta G_{3}^{\circ}\right) /(6 F)
$$

where $\Delta G_{3}^{\circ}$ is the standard Gibbs energy of reaction (3) and $F$, the Faraday constant.

Figure 2 shows the temperature dependence of the EMF of the cell shown above. The data points in this figure lie on almost a straight line which can be represented, after a least squares fit to the data, as

$$
E / \mathrm{mV}=2.92 \times 10^{2}-9.20 \times 10^{-2} \mathrm{~T} / \mathrm{K}
$$

By using equation (4), the standard Gibbs energy of reaction (3) can be calculated as

$$
\Delta G_{3}^{\circ} / \mathrm{kJmol}^{-1}=-1.69( \pm 0.01) \times 10^{2}+5.32( \pm 0.24) \times 10^{-2} \mathrm{~T} / \mathrm{K}
$$

After combining the value of $\Delta G_{3}^{\circ}$ with the standard Gibbs energies of formation of $\mathrm{Y}_{2} \mathrm{O}_{3}$ and $\mathrm{Cr}_{2} \mathrm{O}_{3}$, the following expression is obtained for the standard Gibbs energy of formation of $\mathrm{YCrO}_{3}$

$$
\Delta G_{\mathrm{f}\left(\mathrm{YCrO}_{3}\right)}^{\circ} / \mathrm{kJ} \mathrm{mol}^{-1}=-1.59 \times 10^{3}+2.91( \pm 0.01) \times 10^{-1} \mathrm{~T} / \mathrm{K}
$$

Figure 3 shows the temperature dependence of standard Gibbs energy of formation for some perovskite-type compounds and for $\mathrm{YCrO}_{3}$ as estimated using the data available in 


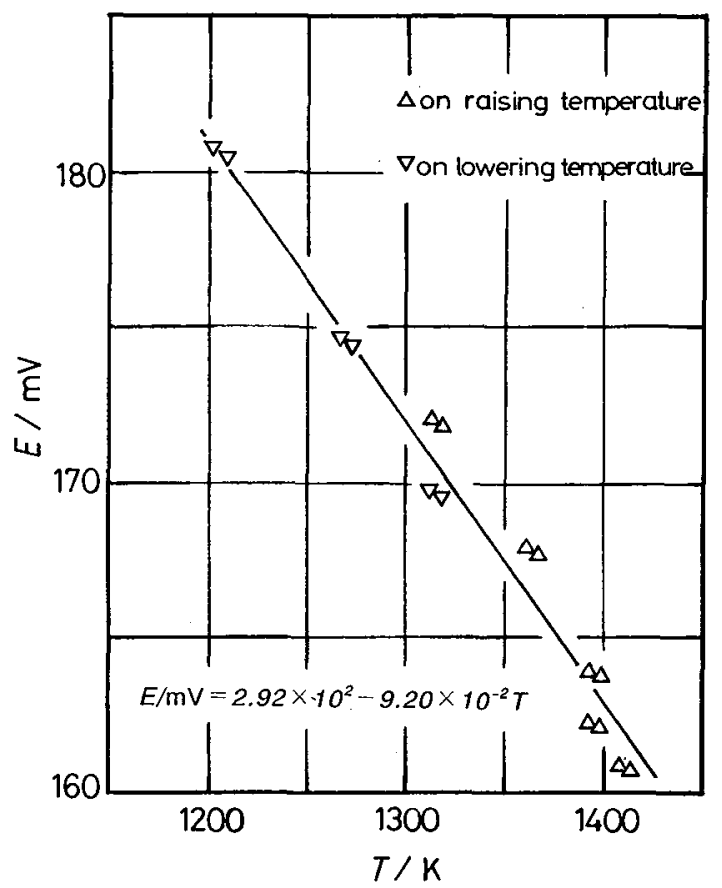

Fig. 2. - The e.m.f. of the cell $\left(\mathrm{Pt}, \mathrm{O}_{2}, \mathrm{Y}_{2} \mathrm{O}_{3}\left|\mathrm{YPO}_{4}\right| \mathrm{YCrO}_{3}, \mathrm{Cr}_{2} \mathrm{O}_{3}, \mathrm{O}_{2}\right.$, Pt) as a function of temperature.

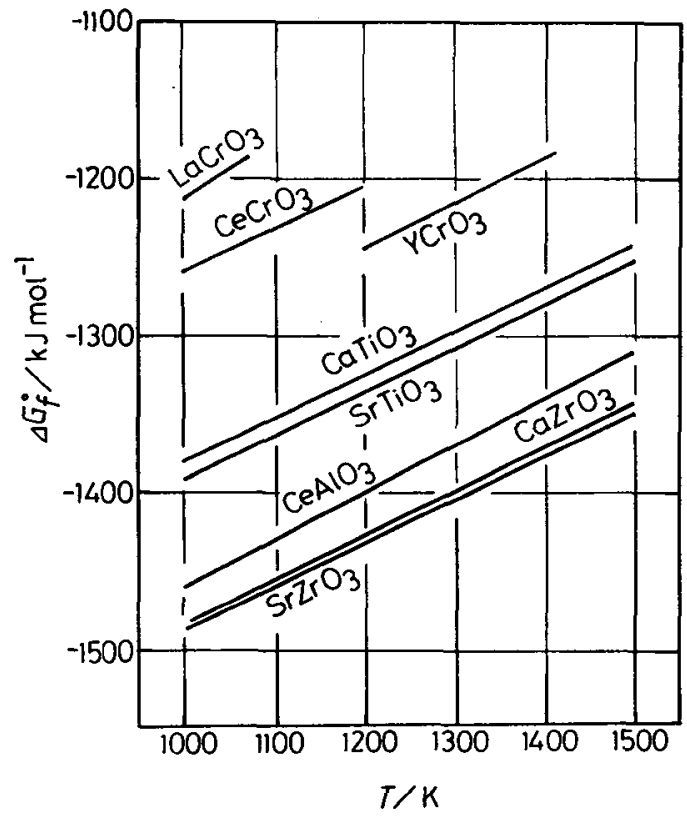

Fig. 3. - Standard Gibbs energy of formation of some perovskite-type compounds and of $\mathrm{YCrO}_{3}$ as a function of temperature. 
the literature $[4,5]$ and equation (7), respectively. Due to the very large negative value of the standard Gibbs energy of reaction (3), $\mathrm{Y}_{2} \mathrm{O}_{3}$ is expected to react with $\mathrm{Cr}_{2} \mathrm{O}_{3}$, at very low oxygen pressures, to form $\mathrm{YCrO}_{3}$. Furthermore, according to the $\mathrm{Cr}_{2} \mathrm{O}_{3}-\mathrm{Y}_{2} \mathrm{O}_{3}$ phase diagram [6], the solubility of $\mathrm{Y}_{2} \mathrm{O}_{3}$ in $\mathrm{Cr}_{2} \mathrm{O}_{3}$ is negligibly small. Therefore, it would be possible for $\mathrm{YCrO}_{3}$ precipitates to form along grain boundaries of $\mathrm{Cr}_{2} \mathrm{O}_{3}$ scales growing over $\mathrm{Y}$ - or $\mathrm{Y}_{2} \mathrm{O}_{3}$ containing alloys as illustrated in figure 1 .

2.2 DEFECT PROPERTIES OF $\mathrm{YCrO}_{3}$. - - The electrical conductivity of $\mathrm{YCrO}_{3}$ was measured by the four-probe d.c. technique at temperatures between 1273 and $1473 \mathrm{~K}$ as a function of oxygen partial pressure. For this purpose, a sintered, parallelpipe-shaped $\mathrm{YCrO}_{3}$ pellet prepared by the drop pyrolysis method was used.

Figure 4 shows the electrical conductivity data for undoped and Ca-doped $\mathrm{YCrO}_{3}$ as a function of oxygen partial pressure. The conductivity of the undoped $\mathrm{YCrO}_{3}$ was almost constant, exhibiting an extrinsic behavior. The substitution of calcium at about 5 at. $\%$ for yttrium in the sample, increased the conductivity by about 2 orders of magnitude. The increase in conductivity, although slight, was observed for oxygen pressures lower than those for the plateau region in figure 4 . This result suggested that p-type conduction was predominant in the Ca-doped sample.

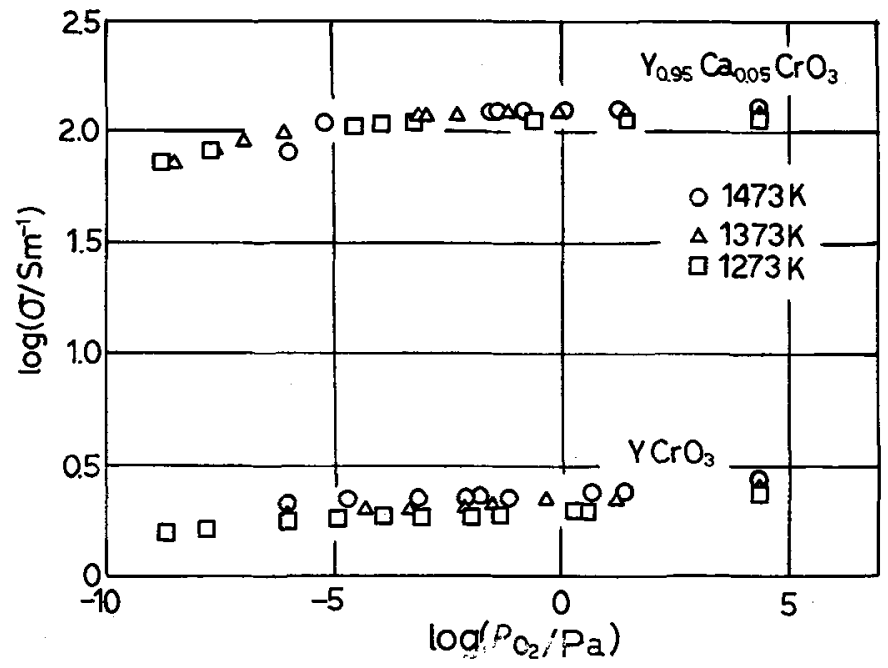

Fig. 4. - Electrical conductivity of undoped and $\mathrm{Ca}$ doped $\mathrm{YCrO}_{3}$ as a function of oxygene pressure.

It can reasonably be assumed that the intrinsic defect structure in $\mathrm{YCrO}_{3}$ is one of Schottkytype and can be expressed as

$$
\text { null } \rightarrow \mathrm{V}_{\mathrm{Y}}^{\prime \prime \prime}+\mathrm{V}_{\mathrm{Cr}}^{\prime \prime \prime}+3 \mathrm{~V}_{\mathrm{O}}
$$

In the p-type region, oxygen is incorporated into $\mathrm{YCrO}_{3}$ through the reaction 


$$
(3 / 2) \mathrm{O}_{2} \rightarrow \mathrm{V}_{\mathrm{Y}}^{\prime \prime \prime}+\mathrm{V}_{\mathrm{Cr}}^{\prime \prime \prime}+3 \mathrm{O}_{\mathrm{O}}^{\mathrm{x}}+6 \mathrm{~h}
$$

Doping by $\mathrm{CaO}$ increases the hole concentration and fixes it at the same concentration as that of $\mathrm{CaO}$ by the reaction

$$
2 \mathrm{CaO}+\mathrm{Cr}_{2} \mathrm{O}_{3}+(1 / 2) \mathrm{O}_{2} \rightarrow 2 \mathrm{Ca}_{Y}^{\prime}+2 \mathrm{Cr}_{\mathrm{Cr}}^{\mathrm{x}}+6 \mathrm{O}_{\mathrm{O}}^{\mathrm{x}}+2 \mathrm{~h}
$$

The mobility of holes in Ca-doped $\mathrm{YCrO}_{3}$ was calculated by using the conductivity data, for this compound, of the plateau region in figure 4 and the known calcium concentration in the sample. The results are shown in figure 5. Furthermore, the concentration of holes in undoped $\mathrm{YCrO}_{3}$ was calculated assuming that the hole mobility in this compound is the same as that in doped $\mathrm{YCrO}_{3}$. Concentrations of holes and other related defects in undopted $\mathrm{YCrO}_{3}$ are given in figure 6 . The hole concentration in the plateau region in this figure is probably determined by the deficiency of yttrium ion which can be indicated as

$$
\mathrm{Cr}_{2} \mathrm{O}_{3}+(3 / 2) \mathrm{O}_{2} \rightarrow 2 \mathrm{~V}_{\mathrm{Y}}^{\prime \prime \prime}+2 \mathrm{Cr}_{\mathrm{Cr}}^{\mathrm{x}}+6 \mathrm{O}_{\mathrm{O}}^{\mathrm{x}}+6 \mathrm{~h}
$$

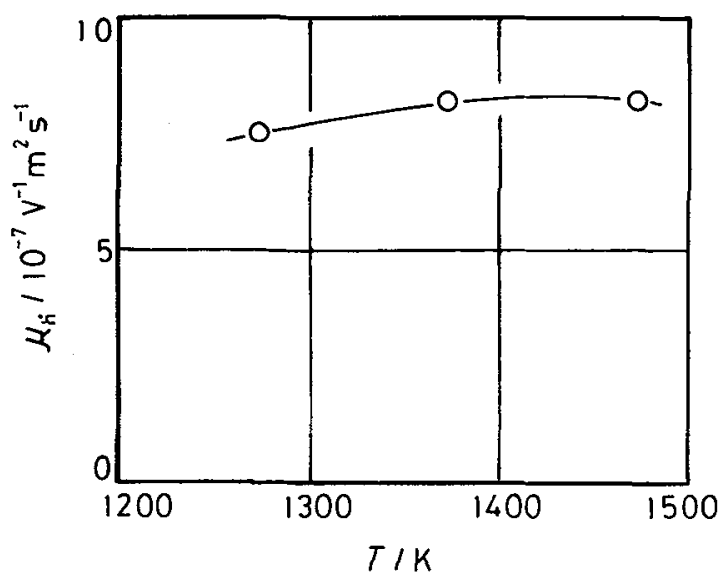

Fig. 5. - Calculated mobility of electron holes in $\mathrm{Ca}$ doped $\mathrm{YCrO}_{3}$ as a function of temperature.

The Kröger-Vink diagram, thus constructed for the undoped $\mathrm{YCrO}_{3}$ is shown in figure 7 . It shows that oxygen vacancy concentration in this compound is high at low oxygen partial pressures; the condition encountered at the alloy-scale interface during high temperature oxidation of alloys. This high vacancy concentration of $\mathrm{YCrO}_{3}$ is expected to increase the diffusivity of oxygen through chromia scales in which such inclusions could be present along the grain boundaries.

Patibandla et al. [7] and Przybylski et al. [8, 9] analyzed the microstructures of chromia scales grown on reactive element ion implanted alloys using electron optical techniques and 


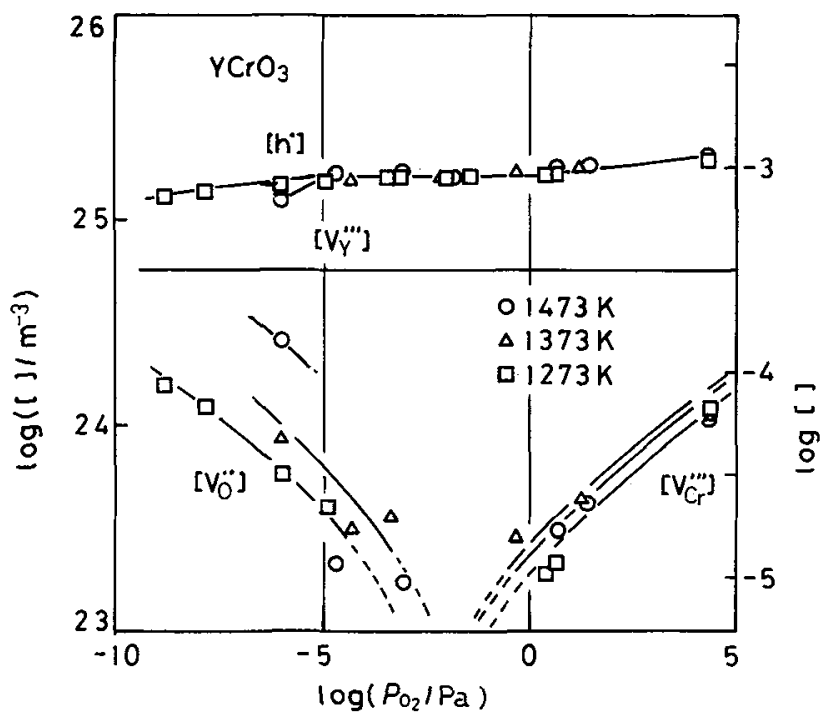

Fig. 6. - Concentrations of defects in undoped $\mathrm{YCrO}_{3}$ as a function of oxygen pressure.

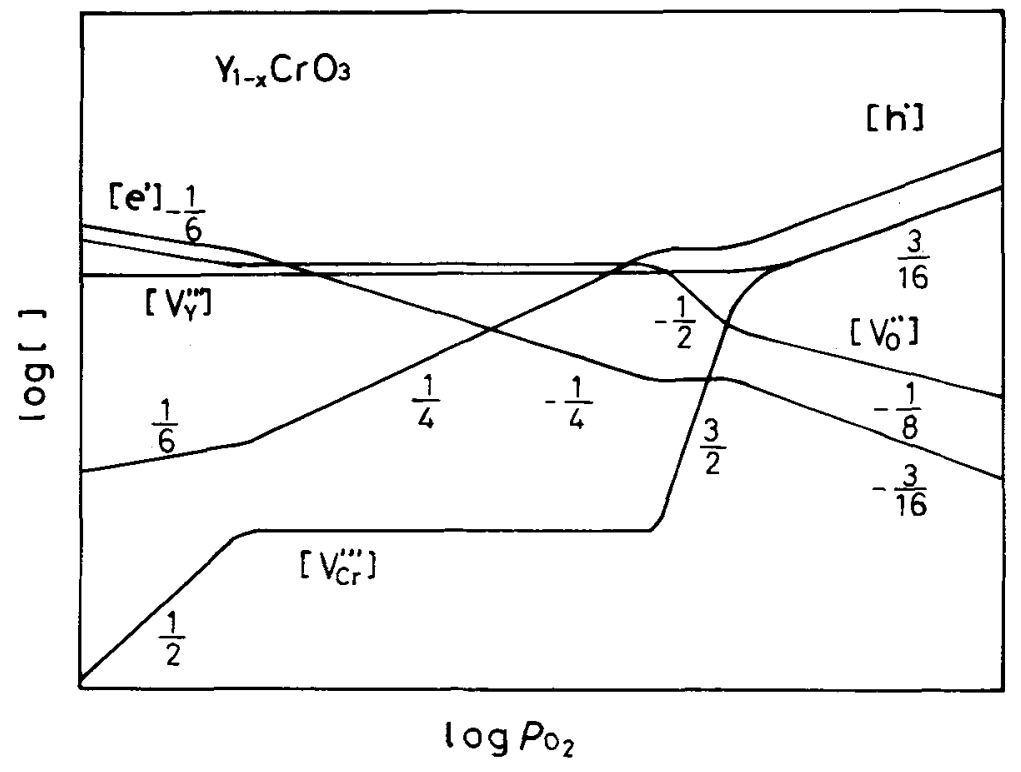

Fig. 7. - The Kröger-Vink diagram for undoped $\mathrm{YCrO}_{3}$.

observed $\mathrm{CeCrO}_{3}$ and $\mathrm{YCrO}_{3}$ in the scale, respectively. These authors also reported a decrease in the growth rate and an increase in the adherence of the chromia scale. They concluded that, for these alloys, scales grew predominantly by inward oxygen diffusion through grain boundaries. In a different study, Landkof et al. [10] identified, by X-ray diffraction, 
$\mathrm{YCrO}_{3}$ in the chromia scale grown over Y-doped 304 stainless steel containing small amount of silicon. The adherence of the scale was found to increase by the yttrium doping and siliconrich precipitates were observed in the alloy close to the alloy-scale interface. These observations provide further experimental support for the model presented in figure 1.

\section{Adherence of oxide scales.}

As mentioned previously, one of the manifestations of the REE is the improvement of the adherence of the alumina and chromia scales under thermal cycling conditions. However, for alloys which contain enough silicon to form silica at the scale base, the situation could be much different. Although it has been suggested, recently, by Hou and Stringer [11] that silicon may act as a reactive element and improve scale adherence, other studies $[12,13]$ indicate that the morphology of the silica layer plays an important role in modifying the scale adherence.

Saito and co-workers [13] reported that spallation characteristics, during cooling, of scales formed over Ni-20 (mass\%) $\mathrm{Cr}-1 \mathrm{Si}$ alloys could be investigated in two stages. The first stage which started around $1000 \mathrm{~K}$, was believed to be the result of thermal stresses generated in the scale due to a difference in thermal expansion coefficients of alloy and oxide. The second stage was observed to be significant around $500 \mathrm{~K}$ and might be attributed to the displacive transformation of cristobalite which involves a substantial volume change.

In a related study, Saito and co-workers monitored, continuously, mass changes of $\mathrm{Ni}-20 \mathrm{Cr}$ $1 \mathrm{Si}$ alloy samples during cyclic oxidation between $1473 \mathrm{~K}$ and two temperatures; one above ( $583 \mathrm{~K}$ ) and another below $(393 \mathrm{~K})$ the $\alpha-\beta$ transformation temperature of the cristobalite phase. The results are given in figure 8 . Here, $(\mathrm{H})$ and $(\mathrm{L})$ refer to temperature cycling between 1473-583 $\mathrm{K}$ and $1473-393 \mathrm{~K}$, respectively. The numbers 18 and 3.6 appearing in this figure refer to the extent of one temperature cycle. Therefore, the total number of cycles corresponding to the data indicated as 18 and 3.6 in figure 8 were 12 and 50 , respectively.

As observed in this figure, scale spallation was not important during thermal cycling between 1473 and $583 \mathrm{~K}$. Samples gained mass continuously, during both the short and long cycling periods. However, spallation was significant upon cycling between 1473 and $393 \mathrm{~K}$. The amount of the spalled scale increased after each cycle between these temperatures. In figure 9, the amount of the scale spalled, up to the third and eleventh cycles in both cycling programs, is shown as a function of the sample temperature. In each case, spallation started around $900 \mathrm{~K}$. For samples which were cooled down to $393 \mathrm{~K}$, the scale spallation was more extensive.

These experiments showed that the adherence of chromia scales grown on Si-containing chromia-forming alloys were degraded by the stresses associated with the $\alpha-\beta$ phase transformation of the cristobalite layer formed at the alloy-scale interface. Microscopical analysis of alloy samples oxidized at $1523 \mathrm{~K}$ for $180 \mathrm{ks}$ showed that Si-rich layers formed at the base of the chromia scale were, indeed, continuous. X-ray diffraction analysis of scales indicated that these layers were of cristobalite.

Saito and co-workers studied, also, the oxidation behavior of $\mathrm{Ni}-20 \mathrm{Cr}-1 \mathrm{Si}$ alloys containing reactive elements such as cerium and lanthanum. In this case, the Si-rich phase developed at the alloy-scale interface was in the form of discrete particles. Adherence of the chromia scale, upon thermal cycling, was observed to have been improved by these additions. In order to investigate a possible REE in the properties of the silica phase observed close to the alloyscale interface, these authors conducted dilatometric studies on $\mathrm{SiO}_{2}-\mathrm{CeO}_{2}$ composites as a function of $\mathrm{CeO}_{2}$ content. 


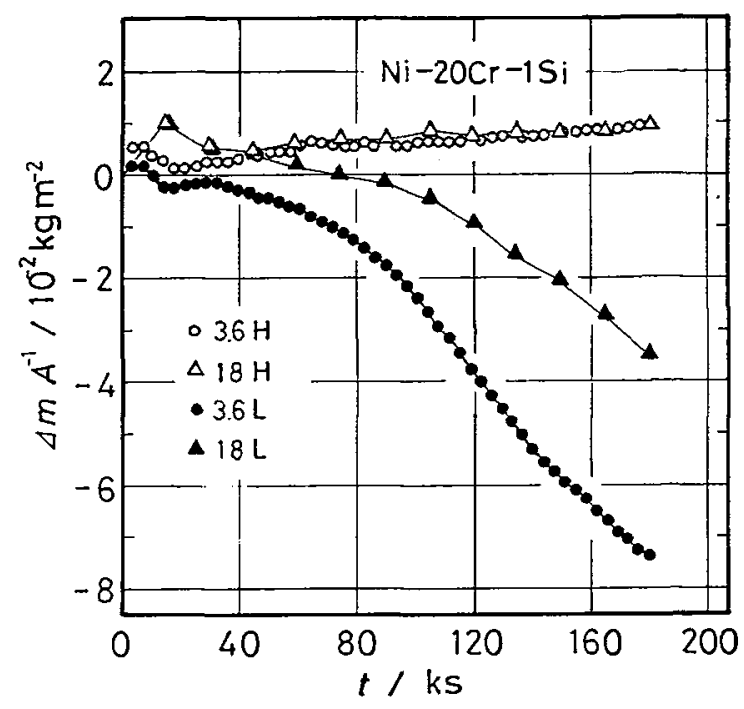

Fig. 8. - Mass changes measured for Ni-20Cr-1Si alloy samples during cyclic oxidation between $1473 \mathrm{~K}$ and two different minimum temperatures (refer text for details).

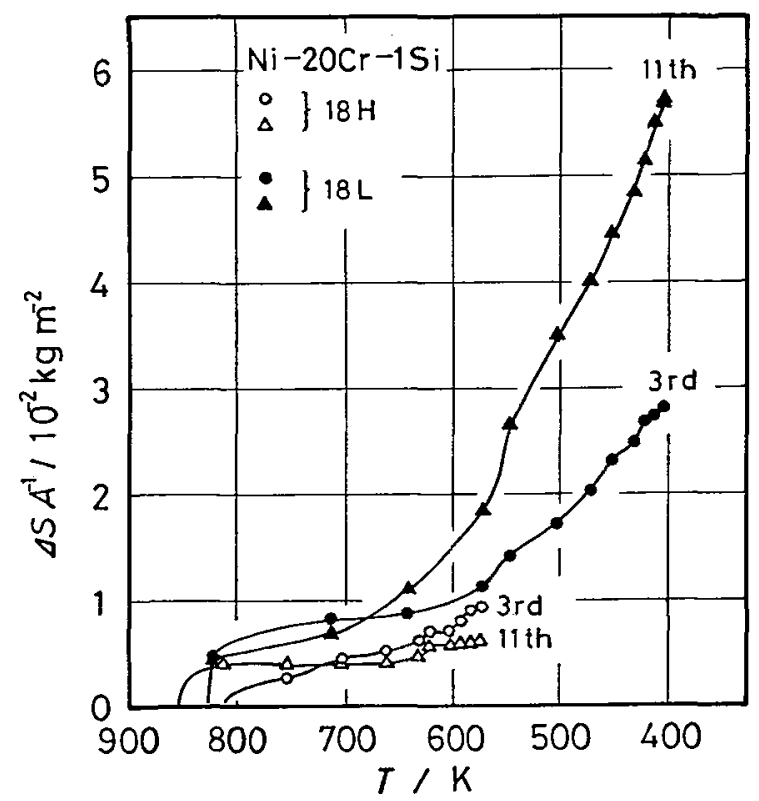

Fig. 9. - Amount of scales spalled from Ni-20Cr-1Si alloy samples at the end of the third and eleventh cycles during cyclic oxidation between $1473 \mathrm{~K}$ and two different minimum temperatures (refer text for details). 
For this purpose, different amounts of ceria powder were mixed with powders of either silicic acid anhydrate or silicic acid hydrate. Powder samples were compacted at room temperature and sintered at $1873 \mathrm{~K}$. X-ray diffraction analysis showed only ceria and cristobalite phases in the samples. The results of the dilatometric tests are shown in figure 10 . All composite samples showed the same type of volumetric change which was associated with the phase transformation in the cristobalite phase. There was no dependence of sample volume change on the ceria content which indicated that ceria did not affect the phase transformation of the cristobalite phase. These results indicated that the improved adherence of the chromia scale over Ce and La containing alloys was, most likely, due to the change in the morphology rather than the composition of the Si-rich inclusions developed close to the alloy-scale interface.

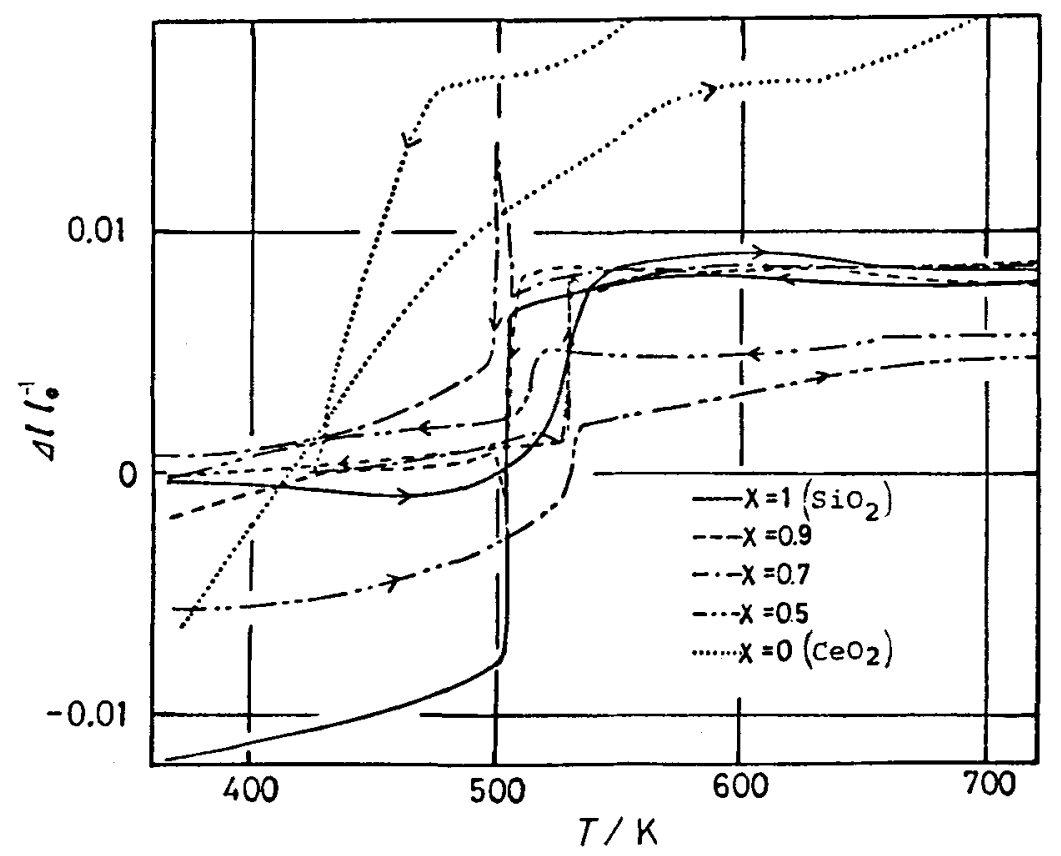

Fig. 10. - Dilatometric data for sintered $\mathrm{SiO}_{2}-\mathrm{CeO}_{2}$ composite samples.

Preliminary data obtained in a different but related study [14] conducted in the authors' laboratory, a similar effect of $\mathrm{Si}$ on the adherence of alumina scales grown on $\mathrm{Fe}-20 \mathrm{Cr}-4 \mathrm{Al}$ alloys was observed. Depending on the sputtering time, silicon sputtered over alloy samples prior to oxidation either increased or decreased the amount of scale spalled during cyclic oxidation between $1473 \mathrm{~K}$ and room temperature. Spallation was observed to increase with the Si sputtering time. In-plane SEM microscopical analysis of the samples suggested a dependence of the development of wrinkled alumina scales on the sputtering time. Since X-ray analysis of scales indicated only $\alpha$-alumina, silicon was believed to have been oxidized to form an amorphous phase in the scale. At higher Si-concentrations in the scale, such amorphous particles are expected to degrade the scale adherence. However, whether the improvement 
in the scale adherence caused by short-term silicon sputtering is related to some sort of REE in alumina-forming alloys, is difficult to conclude at the moment.

\section{The REE on the alumina scale morphology.}

Studies conducted on the REE in alumina-forming alloys reported that the improvement observed in the scale adherence was accompanied by changes in the alumina scale morphology. Golightly et al. [15], for example, concluded that yttrium additions to Fe-base alloys eliminated the development of wrinkles in the alumina scale by preventing new oxide formation at scale grain boundaries which caused high compressive stresses in the scale.

Recently, Saito and co-workers [14] studied the oxidation, in flowing air, of Fe-20Cr-4Al alloys with and without yttrium at temperatures between 1073 and $1273 \mathrm{~K}$. Regardless of the alloy composition, scales formed at $1173 \mathrm{~K}$ over annealed and slightly abraded samples contained protrusions which are referred here as "whisker-like crystals" (WLC). In-plane SEM micrographs of typical scales grown on alloys without and with 0.07 (mass \%) $\mathrm{Y}$ are shown in figures $11 \mathrm{la}$ and $11 \mathrm{~b}$, respectively. These micrographs indicated that both density and size of the WLG developed over the Y-containing alloy were slightly greater than those formed over the alloy without yttrium. Microanalysis of the scales indicated that the WLC were Al-rich. Although X-ray diffraction analysis showed predominantly $\alpha$-alumina in these scales, TEM analysis of one of the scales with WLC suggested the presence of Al-rich phases different than $\alpha$-alumina.
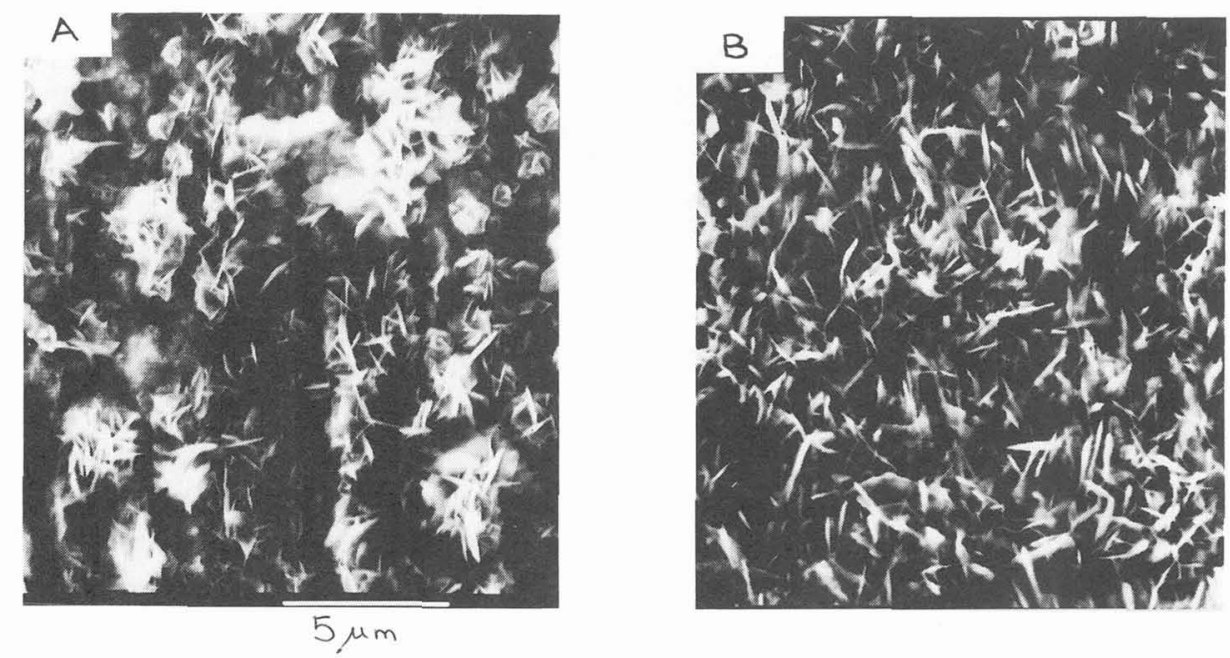

Fig. 11. - In-plane SEM micrographs of typical scales developed over Fe-20Cr-4Al alloys containing: a) no yttrium; b) 0.07 (mass \%) Y after air oxidation at $1173 \mathrm{~K}$ for $54 \mathrm{ks}$.

The development of such "whisker-like crystals" was reported, also, in other studies [1618] conducted on alumina-former alloys. In some of these studies, WLC were identified as of $\theta$-alumina. Because they were observed after oxidation times as long as $162 \mathrm{ks}$ in the present study, these WLC were different than the protrusions observed by others [16] as 
part of the transient oxides which develop during earlier stages of oxidation. The observed increase in the density of the WLC over the Y-containing alloy (Fig. 11) suggested an effect of yttrium on their nucleation. This suggestion is consistent with the nucleation stage of the model presented in figure 1a and proposed by others [19] that reactive elements could affect nucleation of the oxide phase stable at the test temperature by providing easy nucleation sites.
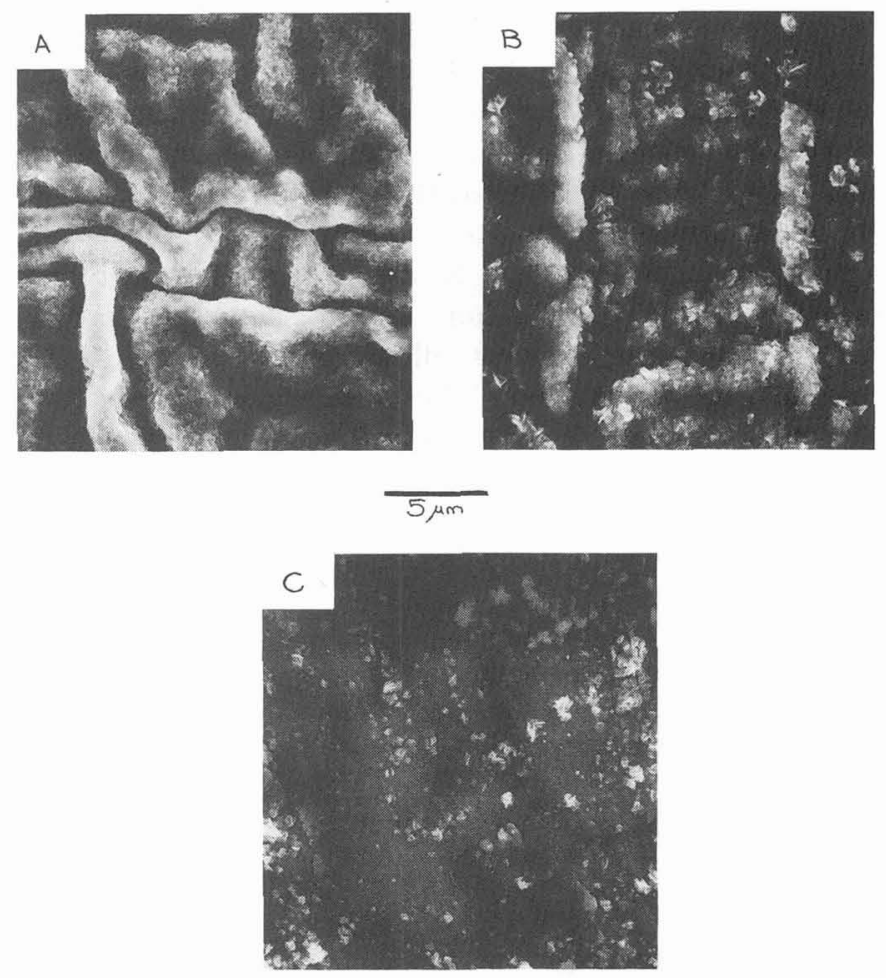

Fig. 12. - In-plane SEM micrographs of typical scales developed over Fe-20Cr-4Al alloys containing: a) no yttrium; b) $0.07 \mathrm{Y}$; c) $0.46 \mathrm{Y}$ after air oxidation at $1273 \mathrm{~K}$ for $24 \mathrm{ks}$.

In the same study, alloys without yttrium formed wrinkled $\alpha$-alumina scales at $1273 \mathrm{~K}$. "Whisker-like crystals" were not observed in these scales (Fig. 12a). In the case of alloys with yttrium, however, scales had less wrinkles at this temperature. In fact, the extent of wrinkling in the scale was observed to decrease with the increasing yttrium content in the alloy (Figs. $12 \mathrm{~b}, \mathrm{c}$ ). Scales grown over Y-containing alloys also contained varying amounts of WLC at $1273 \mathrm{~K}$. This observation was taken as an indication of the REE on the stability of the WLC in the scale. The discussion on the effect of the reactive element-oxides promoting the nucleation of the stable oxide can be extended to explain this observed REE on the stability of the WLC at $1273 \mathrm{~K}$. Although the stability of alumina phases such as $\theta$-alumina is expected to be low at $1273 \mathrm{~K}$, yttrium which would oxidize during very early stages of oxidation could promote the nucleation of the WLC over the alloy even at $1273 \mathrm{~K}$. On the other hand, the apparent decrease in the amount of scale wrinkling for Y-containing alloys is believed to be related to the REE in reducing the growth stresses in the scale as discussed by Golightly et 
al. [15]. These authors postulated that yttrium prevented the outward aluminum diffusion in the scale thus, promoting scale growth by only inward oxygen diffusion along scale grain boundaries. Observation of short, stubby WLC over $\alpha$-alumina scales in figures $12 \mathrm{~b}$, c could be taken as an indication of reduced aluminum outward diffusion in the scale. Since the WLC are believed to have been formed during the earlier stages of oxidation, their presence at the scale-gas interface after oxidation indicate, indirectly, that the smooth-appearing $\alpha$-alumina scale over $\mathrm{Y}$-containing alloys grew at the alloy-scale interface by inward oxygen diffusion.

\section{Conclusions.}

1) For $\mathrm{Cr}_{2} \mathrm{O}_{3}$-forming alloys to which alloying or surface additions of oxygen-active elements such as Ce, Y, La, etc. are made, the observed reactive element effect (REE) may be related to the formation of perovskite-type compounds such as $\mathrm{YCrO}_{3}$ and $\mathrm{CeCrO}_{3}$ in the growing scale. $\mathrm{YCrO}_{3}$, for example, has large, negative standard Gibbs energy of formation and high concentration of oxygen vacancies at temperatures and oxygen pressures encountered in thermally-grown oxide scales.

2) Although one of the observed REE in high temperature oxidation is the improvement of the scale adherence, for alloys containing silicon the adherence is degraded by the $\alpha-\beta$ phase transformation in cristobalite at temperatures between 393 and $583 \mathrm{~K}$. The reactive element/oxide additions to such alloys are effective as long as continuous cristobalite layers do not develop close to the alloy-scale interface.

3) The reactive element/oxide additions to $\alpha-\mathrm{Al}_{2} \mathrm{O}_{3}$-forming alloys increase the stability of metastable alumina phases at temperatures less than $1273 \mathrm{~K}$, probably, by providing easy nucleation sites. At higher temperatures, the additions promote the formation of morphologically-uniform alumina scales which grow by inward oxygen diffusion.

\section{References}

[1] SAITO Y., ÖNAX B., Surf. Coat. Tech. 43/44 (1990) 336.

[2] STRINGER J., Mater. Sci. Eng. A120 (1989) 129.

[3] Saito Y., Maruyama T., Proc. MRS Int. Meet. on Advanced Materials, Composites, Corrosion/Coating of Advanced Materials, vol. 4, M. Doyama, S.Samiya, R.P.H. Chang Eds. (Materials Research Society, USA, 1989) p.345.

[4] AZAd A.M., Sudha R., SREedharan O.M., J. Less Common Met. 166 (1990) 57.

[5] BARIN I., Thermochemical Data of Pure Substances (VCH verlagsgesellschaft, Germany, 1989).

[6] Levin E.M., Mcmurdie, Phase Diagrams for Ceramists, Supplement, M.K. Reser Ed. (American Ceramic Society, USA, 1975).

[7] Patibandla N., Ramanarayanan T.A., Cosandey F., J. Electrochem. Soc. 138 (1991) 2176.

[8] Przybylski K., Garratt-Reed A.J., Yurek G.J.,J. Am. Ceram. Soc. 69 (1986) C-264.

[9] Przybylski K., GarratT-Reed A.J., Yurek G.J., J. Electrochem. Soc. 135 (1988) 509.

[10] LANDKof M., LeVy A.V., BoONE D.H., GRAY R., YANIV E., Corrosion 41 (1985) 344.

[11] Hou P.Y., Stringer J., Oxid. Met. 33 (1990) 357.

[12] STOTT F.H., GabRiel G.J., Wei F.I., WoOD G.C., Werkst. Korros. 38 (1987) 521. 
[13] Saito Y., Maruyama T., Amano T., Mater Sci. Eng. 87 (1987) 275.

[14] IsHIDA S., M.S. Thesis Tokyo Institute of Technology (Japan, 1992).

[15] Golightly F.A., STOTT F.H., Wood G.C., Oxid. Met. 10 (1976) 163.

[16] Golightly F.A., WOOD G.C., STOTT F.H., Oxid. Met. 14 (1980) 217.

[17] RyBicki G.C., SMiALEK J.L., Oxid. Met. 31 (1989) 275.

[18] SiGLER D.R., Oxid. Met. 36 (1991) 57.

[19] STRINGER J., WilcoX B.A., JAFFEe R.I., Oxid. Met. 5 (1972) 11. 